\title{
Relationship between Cash Reserve Ratio and Access to Credit by Micro, Small and Medium Enterprises in Kisumu County, Kenya
}

\author{
Osir Rosalyne Adhiambo, Dr Chesoli Joshua Wafula, Prof Ngacho Christopher
}

\begin{abstract}
The effectiveness of monetary interventions in controlling the supply of money to the micro, small and medium enterprises is acknowledged by scholars and practitioners. However, the mechanism by which such interventions improve access to credit by micro, small and medium enterprises is not fully understood. This study fills this research gap by investigating the relationship between monetary interventions and access to credit by micro, small and medium enterprises in Kisumu County, Kenya. The specific objectivewas to assess the relationship between cash reserve ratio and access to credit. The target population consisted of all the 1,472 micro, small and medium enterprise groups registered at the department of Social Services in Kisumu County, Kenya. A confidence level of $95 \%$ was adopted to obtain a representative sample based on the formula by Yamane Taro. A closed ended survey instrument was administered to a stratified sample of finance managers of the sampled 380 micro, small and medium enterprises. A Cronbach's alpha of 0.801 confirmed the reliability of the instrument while its validity was assessed by expert opinion of finance professionals. Data diagnostic tests and descriptive analysis provided a basis for the inferential analysis, based on correlation and regression analysis. Results show cash reserve ratio has a statistically significant influence on access to credit. These findings have significant implications for the theory, policy and practice of microfinance and central banking in Kenya and beyond.
\end{abstract}

Index Terms - cash reserve ratio, access to credit, MSMEs, entrepreneurs.

\section{INTRODUCTION}

The objective of this thesis is on the relationship between monetary interventions and access to credit among micro, small and medium enterprises (MSMEs). This is an important research issue given the important role of MSMEs in the economy and the potential of access to credit to enhance this role. However, little empirical attention has been given to the mechanism by which monetary policy and access to credit by MSMEs are linked. Thus a need exists for research to open the "black box" between monetary interventions and access to credit by micro, small and medium enterprises. The current study fills this empirical gap by examining the relationship between monetary interventions and access to credit by these enterprises.

The global study on monetary interventions by (Dhungana, 2016) explains that the effects of monetary interventions on access to credit are different in different nations and are more underdeveloped in the developing nations. For developing countries, the use of certain instruments may not bear fruits owing to the underdeveloped nature of their monetary system. In Nigeria, several monetary intervention tools such as OMOs have been in use since 1993 even though their inflation rate has not dropped to the desired unit digit. Like other nations of the world, the Central Bank of Nigeria has the mandate of formulating and implementing their monetary policies with an objective of keeping up price stability (Onwumere, Imo \& Ugwuanyi, 2012).

In Kenya, Kamau (2015) also asserts that monetary interventions are used by the Central Banks worldwide to control the supply of money in the economy to manage prices, gain full employment and promote economic growth. (Kimani, 2013) further notes that the interventions are supposed to guide bank lending rates to limits where the growth of money and the demand for credit are at par with total supply. When the monetary interventions are well implemented and banks become innovative, then access to credit and information by the MSMEs among other sectors may be enhanced. Monetary interventions can be contractionary such that they reduce money supply and bring down inflation rates or expansionary by increasing money supply hence enhancing economic growth by reducing interest rates (Kamau, 2015).

Nyorekwa and Odhiambo (2014) did an assessment of the monetary policy frameworks and the related achievements in Kenya from 1963-2014. They noted that Kenya had undergone varied reforms since 1963, changing from the direct to the indirect monetary interventions in the 1990s. They found that in spite of the monetary policies being inert in the 1960s and early 1970s, the related macroeconomic achievements reflected in the high rates of growth, excess balance of payments and low inflation rates in that era has not been replicated. They also found that despite Kenya's financial sector being among the most developed in Sub-Saharan Africa, after Nigeria and South Africa, the sector still experiences a myriad of challenges of which rapid financial innovations is among them.

The key instruments of intervention in the money markets include interest rate cap (IR caps), cash reserve ratio, open market operations and moral suasion.

The cash reserve ratio is the minimum fraction of notes and deposits by customers that every commercial bank should hold as reserves (Cesar, 2013). The Central Banks can give a law that would curtail surplus reserve so as to control inflation or depreciation. They may also lower reserve ratio if the demand for reserve exceeds the supply (Gray, 2011).

Different studies on cash reserve ratio have been conducted in various countries worldwide. For instance, Zheng and 


\section{Relationship between Cash Reserve Ratio and Access to Credit by Micro, Small and Medium Enterprises in Kisumu County, Kenya}

Spiegel (2017) posits that China changes its reserve ratios regularly as a means of reducing the economic fluctuations. These changes may influence the total supply of credit or the redistribution of credit and capital. They noted that The People's Bank of China had revised its reserve ratio more than 40 times from $8.5 \%-21.5 \%$ between the periods 2006-2011. Evidence indicated that a rise in reserve requirements benefits China's more productive sectors as opposed to the less productive state-owned enterprises by increasing off-balance sheet loans.

Cesar (2013), studying on the evolving role of reserve requirements in monetary policy in Peru noted that in the late 1980s and 1990s literature focused on the use of reserve requirements as a monetary policy instrument to stabilize money supply. He noted that banks maintain reserves to meet demand for liquidity, to control money quantity and manage credit availability.

Gloker and Towbin (2012) on the other hand studied reserve requirements for price and financial stability in France. They inquired on the conditions under which reserve requirements were applicable as a monetary policy tool for price and financial stability. They established that reserve requirements could support price stability if financial frictions were important to an economy.

Zuzana, Riikka and Weill (2015) on the contrary did a study on reserve requirements and the bank-lending channel in China. Their study investigated how the reserve requirements influenced the transmission of monetary policy through the bank-lending channel in China. They noted that the implementation of the Chinese monetary policy is dependent on reserve requirements as a main policy tool. They analyzed the reaction of loan supply on changes in reserve requirements and found that changes in reserve requirements did influence the loan growth of banks in China.

Jamel, Alqalawi, Ahmed and Rasha (2017) in their study on the influence of indirect monetary tools on price and output in Jordan found that reserve requirements had a positive effect on money supply. Dhungana (2016) however in his study on the effects of monetary policy on bank lending in Nepal found a negative relationship between reserve requirements and bank lending.

The law in Kenya requires that Commercial Banks (CBs) remit about $6 \%$ of their deposits with the Central Bank of Kenya which is used to determine the amount of loans that banks can lend to the public hence influencing the supply of funds. When the ratio of the required reserve is increased, the loanable funds for commercial banks decrease while a reduction in the ratio increases the loanable funds available (Putunoi, 2015).

The global problems of MSMEs relate to their inability to access credit they require, to contribute to economic development, employment creation and poverty reduction (Etemesi, 2017; Ghulam and Mumbine, 2017). In the developed world the MSMEs contribute a large share of the GDP and employ over $50 \%$ of the total workforce. In Netherlands MSMEs compose of about $90 \%$ of the private sector, contribute to about $32 \%$ of the GDP and employ $55 \%$ of the labor force. The role of MSMEs can be enhanced if they are given better access to credit policies that promote their ability to expand and develop (Ghulam and Mumbine, 2017). The need for specific interventions is evident from the fact that MSMEs are often seen as high risk and less viable economically by lenders.

However, governments across the world are refocusing on MSMEs as endeavors to improve economic growth via large industries have failed. Many developed countries have heightened the credit guarantee schemes for their MSMEs. For instance, in 2014, France eased the lending rules for MSMEs such that the loan guarantee schemes covered up to $90 \%$ of the risks pertaining to loans, the UK guaranteed up to $75 \%$, Japan $80 \%$ and South Korea $100 \%$ of the MSMEs. Other countries such as Belgium and Sweden lend directly to the MSMEs through their public institutions or state-owned banks (Etemesi, 2017).

The success stories of many industrially advanced nations that recognize the place of MSMEs in their economic development have persuaded the African Nations to acknowledge and support the emergence and sustenance of the MSMEs in their national development plans, albeit with slow success. For instance, in South Africa SMEs hardly operate beyond their fifth years due to lack of financial acumen among others (Ndede,2015), while in Uganda collateral is up to $150 \%$ of loan advanced, repayment period is only up to 24 months and interest rates are between $23 \%$ to $30 \%$ per month (Etemesi,2017).

Deressa (2014) noted that inaccessibility to credit by the MSME sector in Zambia was a major hindrance in doing business which impacted on their growth extensively. This view find support in Ethiopia, where Alemu (2017) found that inaccessibility to finance interfered with the growth and efficacy of the MSMEs. Avevor (2016) report that financial institutions in Ghana considered MSMEs a risky industry hence offered them credit at high interest rates. These studies may however not fully explain the extent of access to credit following monetary interventions in Kenya.

Related literature however points to the sector's importance in employment creation and economic growth. The MSME sector in Kenya is still facing challenges relating to credit access such as lack of collateral, financial illiteracy, high interest rates and lack of information (Ndede, 2015). Arora (2010) notes that some dimensions of access to finance such as easy physical access, flexibility, reliability, ease to undertake transactions, cost dimension, and access by the less privileged and financially illiterate. The current study investigates some of these dimensions of the dependent variable MSMEs access to credit. To test the hypothesized relationship between cash reserve ratio and access to credit, the current study focused on MSMEs operating in Kisumu County, Kenya.

Kisumu County is one of the devolved counties in Kenya and is divided into seven sub-counties of Kisumu East, Kisumu West, Kisumu Central, Seme, Nyando, Muhoroni and Nyakach. It has a population of 968,909 on a land area of 2085.9 sq. km. Kisumu city, as the administrative hub of the County was considered a suitable study location since it is a leading commercial, trading, fishing and industrial hub in Lake Victoria basin (CIDP Kisumu, 2019). It has a rich mix of MSMEs involved in trade, transport, service, agriculture, hotel, health, education and industry. Surprisingly, while it may be expected that involvement of MSMEs can alleviate poverty and reduce unemployment, the reverse appears to be the case. 
According to its recent County integrated development plan (2019/2020) lack of access to credit remains a major impediment faced by MSMEs in the County. In is not surprising to note that the intervention by the County Government of Kisumu is yet to translate into enhanced contribution by MSMEs to poverty reduction and economic growth (Indimuli, Mukami, Lambart and Mwangi, 2015). These initiatives include central and county governments' intervention schemes such as Youth and Women Enterprise Funds, Poverty Eradication Funds and the Kisumu County Traders' Fund. Despite these efforts recent studies suggest that financial shortage as a major challenge faced by the MSMEs in Kisumu (Orinda, 2014). The current study investigated the relationship between monetary interventions and MSMEs' access to credit.

\section{STATEMENT OF THE PROBLEM}

The current study examines the problem of lack of access to credit faced by MSMEs. This problem curtails their ability to contribute to solving the problem of unemployment and poverty. To address this challenge Governments around the world have introduced monetary interventions aimed at increasing the supply of credit to MSMEs. In Kenya the challenge seems to persist as studies point to lack of access as a major impediment for MSMEs. This suggests the need for a wider conceptualization of the problem of lack of access to credit by MSMEs.

The government, at county and national level has set up funds to provide the MSME sector. These include the Fund for the Inclusion of Informal Sector (FIIS) to allow MSMEs to access credit facilities expand their businesses and increase their savings. The fund also aims to help informal enterprises transition to formal sector enterprises, through access to formal providers of financial services. FIIS is a revolving fund through which the government enters into credit facility agreements with select banks for lending to micro-and small-enterprises through branches, authorized banking agents and other channels, particularly mobile banking. At County Government levels MSMEs have benefited from funds such as Youth Enterprise Fund, Women Enterprise Fund, Uwezo Fund and Kisumu Traders' Fund among others (KCIDP, 2013).

The paradox is that despite monetary interventions, MSMEs seem to be having problems accessing credit. This problem has been attributed to increased costs of credit, repercussions of interest rate cap and also lack of collateral (Etemesi, 2019; Ndede, 2018). Evidently, without an empirical investigation we would remain unaware of the mechanism by which monetary policy translates to access to credit by MSMEs. An empirical investigation can shed light on the link between monetary interventions and access to credit. This thesis answers this need by focusing on the research problem of establishing the relationship between monetary interventions and access to credit by MSMEs. The study seeks to answer the question of whether there is a relationship between monetary interventions and access to credit in Kenya.

\section{III.}

\section{RESEARCH DESIGN AND METHODOLOGY}

This study adopted a diagnostic research design as it was important to establish causal relationships between the independent and the dependent variable. Micheal (2000) states that diagnostic research studies describe cause-effect relationships in which diagnosis is made by which frequency of effect in the event of the occurrence of a cause is determined. Kothari (2004) avers that both descriptive as well as diagnostic studies share common requirements and as such may be grouped together.

Descriptive studies are those which are concerned with describing the characteristics of a particular individual, or group, whereas diagnostic research studies determine the frequency with which something occurs or its association with something else (Micheal,2000; Saunders, Lewis and Thornhill,2003). The design in such studies focus on formulation of the objectives, designing methods of data collection, selecting the sample, collecting the data, processing and analyzing the data and reporting the findings (Kothari, 2004; Micheal,2000).

This study was conducted in Kisumu County which is a leading commercial, trading, fishing, industrial and administrative County in Lake Victoria basin. This county was chosen as a study area owing to the potential of monetary interventions to improve access to credit by MSMEs which employ over $90 \%$ of the population in this region. Access to credit can enhance the role of MSMEs in poverty alleviation, redistribution of incomes, and address other social economic challenges facing the inhabitants of the Lake Victoria basin.

Kisumu County was chosen for the study being a county where high indices of poverty, income inequalities and social ills have stunted its growth and development and which in turn hinder access to opportunities. Economic interventions among others are therefore necessary so as to address the effects of the social and economic issues (KCIDP, 2013).

This study targets the micro, small and medium enterprises within Kisumu County. The population of the MSMEs is large and scattered and could be termed as infinite. Therefore the registered MSMEs within Kisumu County, in particular Kisumu Central and Kisumu East sub counties, are purposively selected as the population. This gives a total population of 1,472 registered groups of SMEs as per the Department of Social Services Kisumu County, 2020. The units of analysis are the MSMEs whereas the groups were the units of study. The instrument was filled by their finance managers.

The appropriateness of using Yamane Taro's formula for obtaining a sample size in similar studies is acknowledged (Singh and Masuku, 2014). According Yamane Taro, the sample size is obtained at a confidence level of $95 \%$ using the formula: $n=\frac{N}{1+N(\theta)^{2}}$ where $\mathrm{n}$ is the sample size, $\mathrm{N}$ is the population size and $\mathrm{e}$ is the precision level. Therefore from a population of $1472, n=\frac{1472}{1+1472(0.05)^{2}}=315$. Hence the minimum required sample size is 315 SMEs. Based on the response rates in similar studies this figure was adjusted.Maina (2015) obtained a response rate of $83 \%$ in a similar study. Considering $17 \%$ as a typical non response rate the sample size is adjusted to be: $\mathrm{n}=\frac{100}{9 a} \times 315=380$. Where $\mathrm{n}=$ Sample size. In the current study, the sample size of 380 was considered adequate to cater for the typical non-response in similar studies.

The sample frame consisted of all the 1472 MSME groups registered by the Department of Social Services within Kisumu County. The finance managers of 380 MSME groups were chosen as the key informants. They were deemed knowledgeable in the issues under investigation in this study. 


\section{Relationship between Cash Reserve Ratio and Access to Credit by Micro, Small and Medium Enterprises in Kisumu County, Kenya}

To obtain the sample of the Finance Managers of the MSMEs, stratified random sampling technique was employed since the population is heterogeneous (Singh and Masuku, 2014). The population was divided into homogeneous strata with respect to specific groups. The units

\begin{tabular}{|c|c|c|c|}
\hline Population Strata & Population & Percentage & Sample \\
\hline CBO Kisumu Central & 51 & 3.5 & 13 \\
\hline Youth Groups Kisumu Central & 160 & 10.9 & 41 \\
\hline WomenGroups Kisumu Central & 181 & 12.3 & 47 \\
\hline Self-help Groups Kisumu Central & 514 & 34.9 & 133 \\
\hline CBO Kisumu East & 42 & 2.9 & 11 \\
\hline Youth Groups Kisumu East & 68 & 4.6 & 18 \\
\hline Women Groups Kisumu East & 172 & 11.7 & 44 \\
\hline Self-help Groups Kisumu East & 284 & 19.3 & 73 \\
\hline Total & 1472 & 100.0 & 380 \\
\hline
\end{tabular}

Source (Department of Social Services Kisumu County, 2020)

The current research was based on primary data collected by use of a survey instrument which was administered to 380 finance managers of the MSMEs registered by the Ministry of Social Services in Kisumu County.

The instrument used for collecting data in the current study was a questionnaire. The questionnaire consisted of a section capturing characteristics of respondents and three sections focusing on their opinion about the relationship between monetary interventions and access to credit in the MSME sector. A five-point likert rating scale was used to measure the opinions of the respondents relating to the role of financial innovations in the relationship between monetary interventions and access to credit by MSMES operating within Kisumu County.

The questionnaire was administered with the researcher, with the assistance of research aids that issued and waited for the questionnaires to be completed by finance managers. Where the managers were busy, the research assistants noted the time and place from which the instrument would be collected and thereafter went back for collection. The research assistants were trained for two days on administration of questionnaires before being engaged in the study.

To make the test instrument more reliable items were written clearly, test instructions clearly articulated for easy understanding, research assistants were effectively inducted and the questions made sufficiently many. Reliability test was carried out to determine the internal consistency of the parameters being studied. As a result the instrument to be used for collecting data was pilot tested by using 38 MSMEs from Vihiga town within Vihiga County. This is $10 \%$ of the sample as per (Saunders et al., 2003). Internal consistency reliability was tested using the Cronbach's alpha of which a coefficient of 0.801 was obtained during the pilot study. This was satisfactory according to (Kimberlin and Winterstein, 2008).

Validity is a measure of how well the instrument measures what it is intended to measure Kimberlin and Winterstein, 2008). Expert knowledge of supervisors, research experts and piloting of the instrument ensured content validity of the instrument. The results of the pilot tests were used to refine the final questionnaire. Both descriptive and inferential were then sampled at random from each of these strata. The samples per strata were obtained proportionately. The resulting sample is shown in Table 1. statistics were employed for analysis. The descriptive statistics included averages, frequencies and percentages presented in tables. The data was represented in frequency distribution tables. The analysis was quantitative. The unit of analysis was the MSMEs within the registered groups who are actively in business.

Data collected was coded and fed into the Statistical Package for Social Sciences (SPSS) for analysis. Correlation analysis and regression analysis were conducted to find relationships and correlations. F-test (ANOVA) was conducted to assess the overall robustness and significance of the regression model. T-test on the other hand was conducted to determine the individual significance of the relationships. Hypothesis testing was carried out after correlation analyses and simple linear regression analysis for each hypothesis. The regression analyses provided equations which were used to estimate the magnitude of the dependent variable and the predictor variables. Pearson's moment correlation (r) was used to show the strength and nature of relationships among the variables and coefficient of determination $\left(\mathrm{R}^{2}\right)$ was used to measure the amount of variations between the variables. The general models for predicting credit access were as shown below: $Y=\beta_{0}+\beta_{2} X_{2}+\varepsilon_{i} ; \ldots \ldots \ldots \ldots \ldots \ldots \ldots \ldots \ldots \ldots \ldots$. Model 2

Where $\mathrm{Y}$ is the composite index of credit access by MSMEs in Kisumu County,

$X_{2}$ is the composite index of reserve ratio $\beta_{2,}$ is the regression coefficient for cash reserve ratio.

$\beta_{0}$ is the $y$-intercept and $\varepsilon_{\mathrm{i}}$ are the random error terms accounting for variability in credit access.

The regression models for testing each of the hypotheses are as follows:

$\mathrm{H}_{2}: \mathrm{Y}=\beta_{0}+\beta_{6} X_{2}+\varepsilon_{\mathrm{i}}$, where $\mathrm{Y}$ is the composite index of credit access, $\beta_{0}$, is the $y$-intercept, $X_{2}$ is the composite index of cash reserve ratio, $\beta_{6}$ is the regression coefficient of reserve ratio and $\varepsilon_{i}$ is the random error term. 


\section{RESULTS AND DISCUSSION}

\section{A. RESPONSE RATE}

Questionnaires were administered to 380 respondents drawn from the population of 1472 respondents. The researcher and Table 2 Questionnaire return rate

\begin{tabular}{lcc}
\hline Sample size & Number & Percent \\
\hline Distributed Questionnaire & 380 & 100 \\
Returned questionnaire & 342 & 90 \\
Not returned questionnaire & 38 & 10 \\
Non usable questionnaire & 18 & 14.7 \\
Usable questionnaire & 324 & 85.3 \\
\hline
\end{tabular}

\section{Source: Field data (2020)}

In Table 2, out of the three hundred and eighty (380) total questionnaires administered, 342 were filled and returned representing $90 \%$ of the total questionnaires administered. However, of the 342 questionnaires returned, 18 questionnaires representing $14.7 \%$ were incomplete and could not be used for further analysis. Therefore, 324 questionnaires were legible for further analysis. This gave a response rate of $85.3 \%$. The overall response rate of $85.3 \%$ is above the minimum recommended for analysis and reporting (Mugenda, 2003). A return rate of 50\% is adequate for analysis (Babbie, 2003). trained assistants delivered the questionnaires to the finance managers of the 380 registered groups. The response rate is presented in Table 2.

\section{B. DEMOGRAPHIC CHARACTERISTICS OF RESPONDENT}

The researcher presumed that respondents' bio-data had some relationship with the role of financial innovations in the relationship between monetary interventions and access to credit. The major background characteristics included: MSME business sector, size of MSME, MSME source of credit, impediments to credit access, longest loan term, highest loan limit and highest cost of loan.

\section{i. .Distribution of Enterprises by Economic Subsectors}

Respondents were asked to indicate the sector to which they belonged. The distribution of subsector for the sampled MSMEs is presented in Table 3.

Table 3 Distribution of enterprises by economic sector

\begin{tabular}{lcc}
\hline Sector & Frequency & Percent \\
\hline Agriculture & 64 & 20 \\
Transport and warehousing & 55 & 17 \\
Trade & 48 & 15 \\
Industry(processing/ manufacturing/ assembling) & 45 & 14 \\
Service and communication & 42 & 13 \\
Hotel/restaurant/guest house/lodge/bar & 32 & 10 \\
Health & 29 & 9 \\
Education & 9 & 3 \\
Total & $\mathbf{3 2 4}$ & $\mathbf{1 0 0}$ \\
\hline
\end{tabular}

\section{Source: Primary data (2020)}

The data in Table 3 indicate that a fifth (20 percent) of the respondents were from the agricultural sector. The agricultural sector, together with the transport and trade accounted for over half (51percent) of the respondents. A possible explanation of this phenomenon is that the study area is mainly agricultural, as industries are very few and concentrated in Kisumu County. The policy implication is that regulators need to implement selective monetary policies targeting agriculture, transport/warehousing and trade subsectors.

The data in Table 3 also shows that the education subsector is the least represented. This may be attributable to the huge capital requirements for establishing schools. These findings suggest the importance of the agriculture sector and the unimportance of the education sector for policies targeting improving access to credit in Kisumu County. The findings in Table 3 suggest that policies geared towards enhancing access to credit can have more impact if they target the agriculture, transport, warehousing, trade and less impact if they target the education sector.

\section{ii. Size of Firms}

The study used number of employees as a proxy for size of an enterprise. The size of participant firms is presented in Table 4. 
Relationship between Cash Reserve Ratio and Access to Credit by Micro, Small and Medium Enterprises in Kisumu County, Kenya

Table 4 Size of firms

\begin{tabular}{lcc}
\hline Number of employees & Frequency & Percent \\
\hline $0-10$ & 285 & 88 \\
$11-50$ & 36 & 11 \\
$51-100$ & 3 & 1 \\
Total & $\mathbf{3 2 4}$ & $\mathbf{1 0 0}$ \\
\hline
\end{tabular}

\section{Source: Field data (2020)}

The data in Table 4 indicate that the majority of enterprises $(88 \%)$ were micro enterprises with less than 10 employees. While micro enterprises accounted for nearly $90 \%$ of firms surveyed, only $1 \%$ comprised of medium enterprises. Perhaps this implies that most of the surveyed firms may not be in a position to obtain asset backed financing being micro enterprises. Such firms may then benefit from new forms of Table 5 Sources of credit

\begin{tabular}{lcc}
\hline Sources of Funds & Frequency & Percent \\
Kisumu Traders' Fund & 19 & 6 \\
Uwezo fund & 62 & 19 \\
Women enterprise fund & 45 & 14 \\
Youth enterprise fund & 52 & 16 \\
Credit cards & 26 & 8 \\
Mobile money & 45 & 14 \\
Bank loan & 75 & 23 \\
Total & $\mathbf{3 2 4}$ & $\mathbf{1 0 0}$ \\
\hline
\end{tabular}

\section{Source: Survey data (2020)}

In terms of importance, Table 5 shows that bank credit provides 23 percent of the financial needs of micro, small and medium enterprises operating within Kisumu County. Funds set up for enterprise development by the government together provide over half of the needs of micro, small and medium enterprises operating within Kisumu County.

Credit cards issued by banks and non-bank financial institutions account for less than one tenth of the financial resources of micro, small and medium enterprises. Other than credit cards, micro, small and medium enterprises rely on mobile money for $14 \%$ of their financial needs. Financial

Table 6 Impediments to accessing credit

\begin{tabular}{lcc}
\hline Impediment & Frequency & Percent \\
\hline High cost of loans & 104 & 32 \\
Lack of guarantors & 75 & 23 \\
Limited repayment ability & 68 & 21 \\
Lack of sufficient information & 45 & 14 \\
Lack of collateral & 32 & 10 \\
Total & $\mathbf{3 2 4}$ & $\mathbf{1 0 0}$ \\
\hline
\end{tabular}

\section{Source: field data (2020)}

From Table 6 it is evident that the lack of collateral is the least important factor impeding enterprises' access to credit. As evident in Table 6 high cost of loans is the most cited impediment to accessing credit. High cost of loans is the major impediment to accessing credit as almost a third of the respondents in the sector attested to that.

v. Longest Loan Repayment Period

The time allowed for an enterprise to repay credit granted was viewed as a proxy of the risk of loaning a client. Respondents credit heralded by financial innovations that have fewer restrictions on borrowing.

iii. Sources of Credit

The data on the source of credit was also collected to establish the role of financial innovations in enhancing access to credit. Table 5 presents the various sources of credit for micro, small and medium enterprises operating in Kisumu County. innovations thus account for a proportion equal to that of banks.

iv. Impediments to Accessing Credit

The study also considered the problems facing micro, small, and medium enterprises in accessing credit. Table 6 presents the major impediments to accessing credit by micro, small and medium enterprises in Kisumu County. were asked to indicate the longest loan repayment period allowed to the micro, small and medium enterprise. The data in Table 7 presents the findings. 
Table 7 Longest loan repayment period

\begin{tabular}{lcc}
\hline Period(yrs) & Frequency & Percent \\
Up to 1 year & 191 & 59 \\
\hline $1-2$ years & 110 & 34 \\
Over 2 years & 23 & 7 \\
Total & $\mathbf{3 2 4}$ & $\mathbf{1 0 0}$ \\
\hline
\end{tabular}

\section{Source: Field data (2020)}

The data in Table 7 shows that nearly $60 \%$ of enterprises access short term credit. Further, less than $10 \%$ of the credit advanced to these enterprises attracted a repayment period of over 2 years. The findings in Table 7 may be interpreted to mean that these enterprises engage in activities that are viewed to be risky by lenders hence are required to pay up their loans within a short period.

Table 8 Highest loan size

\begin{tabular}{lcc}
\hline Loan size (Kshs) & Frequency & Percent \\
\hline Up to 50,000 & 169 & 52.0 \\
50,000 to 100,000 & 104 & 32.3 \\
100,000 to 200,000 & 29 & 9.0 \\
Over 200,000 & 22 & 6.8 \\
Total & $\mathbf{3 2 4}$ & $\mathbf{1 0 0}$ \\
\hline
\end{tabular}

\section{SOURCE: FIELD DATA (2020)}

The data in Table 8 shows that over half of the credits accessed by enterprises are an amount of less than 100,000. Further, the data shows that more than 90 percent of loans were of less than ksh200000. This may be interpreted to mean that the majority of micro, small and medium enterprises accessed small loan amounts.

\section{C.DESCRIPTIVE STATISTICS}

\section{i. Cash Reserve Ratio and Access to Credit}

Table 9 Cash reserve ratio and access to credit

\section{vi. Highest Loan Size}

Respondents were asked to indicate the highest size of the most recent loans accessed. Table 8 presents the results.
The second objective of the study was to establish the influence of cash reserve ratio on access to credit by micro, small and medium enterprises. Pertinent data was obtained by asking respondents to indicate the extent to which they agreed or disagreed with the statements on the relationship between cash reserve ratio and access to credit. Table 9 presents the means and standard deviations of the responses.

\begin{tabular}{|c|c|c|c|c|c|}
\hline & $\mathrm{N}$ & Minimum & Maximum & Mean & Std. Deviation \\
\hline $\begin{array}{l}\text { An increase in cash reserve ratio } \\
\text { would decrease the number of } \\
\text { MSMEs accessing credit }\end{array}$ & 324 & 1 & 5 & 3.23 & .942 \\
\hline $\begin{array}{l}\text { An increase in cash reserve ratio } \\
\text { would decrease the amount of } \\
\text { loan accessed by MSMEs }\end{array}$ & 324 & 1 & 5 & 3.32 & .886 \\
\hline $\begin{array}{l}\text { An increase in cash reserve ratio } \\
\text { would decrease the cost of loan to } \\
\text { MSMEs }\end{array}$ & 324 & 1 & 5 & 2.95 & .849 \\
\hline
\end{tabular}




\begin{tabular}{|c|c|c|c|c|c|}
\hline $\begin{array}{l}\text { An increase in cash reserve ratio } \\
\text { would decrease the duration of } \\
\text { the loan term to MSMEs }\end{array}$ & 324 & 1 & 5 & 2.70 & .912 \\
\hline GRAND MEAN SCORE & & & & & \\
\hline
\end{tabular}

\section{Source: Field Data (2020)}

As shown in Table 9, an increase in cash reserve ratio would decrease the number of MSMEs accessing credit moderately (Mean $=3.23, \mathrm{SD}=.942$ ). The findings also indicated that an increase in cash reserve ratio would moderately decrease the amount of loan accessed by MSMEs (Mean $=3.32, \mathrm{SD}=$ .886). Similarly, an increase in cash reserve ratio would decrease to a moderate extent the cost of loan to MSMEs. (Mean $=2.95, \mathrm{SD}=.849)$. The findings further revealed that an increase in cash reserve ratio would moderately decrease the duration of the loan term to MSMEs (Mean $=2.70, \mathrm{SD}=$ .912 ).

As shown in Table 9 the mean response rate is 3.05. This means that the respondents agree to a moderate extent that an increase in the cash reserve ratio to would decrease access to credit by micro, small and medium enterprises.

\section{ii. Access to Credit}

The study also analyzed the descriptive statistics for access to credit using, mean and standard deviation. Table 10 highlights the findings on access to credit.

Table 10 Access to Credit

\begin{tabular}{|c|c|c|c|c|c|}
\hline & $\mathbf{N}$ & Minimum & Maximum & Mean & Std. Deviation \\
\hline $\begin{array}{l}\text { Lack of collateral hinders access } \\
\text { to credit by MSMEs }\end{array}$ & 324 & 1 & 5 & 4.14 & .767 \\
\hline $\begin{array}{l}\text { Lack of guarantors hinders access } \\
\text { to credit by MSMEs }\end{array}$ & 324 & 1 & 5 & 4.10 & .711 \\
\hline $\begin{array}{l}\text { Additional charges on loans } \\
\text { hinder access to credit by MSMEs }\end{array}$ & 324 & 1 & 5 & 3.87 & .713 \\
\hline $\begin{array}{l}\text { Short repayment period hinders } \\
\text { access to credit by MSMEs }\end{array}$ & 324 & 1 & 5 & 3.70 & .793 \\
\hline $\begin{array}{l}\text { Lack of sufficient information } \\
\text { hinders access to credit by } \\
\text { MSMEs }\end{array}$ & 324 & 1 & 5 & 3.41 & .892 \\
\hline $\begin{array}{l}\text { Lack of savings accounts by } \\
\text { MSMEs hinders access to credit } \\
\text { by MSMEs }\end{array}$ & 324 & 1 & 5 & 3.13 & .870 \\
\hline $\begin{array}{l}\text { Lack of books of accounts by } \\
\text { MSMEs hinders access to credit } \\
\text { by MSMEs }\end{array}$ & 324 & 1 & 5 & 2.80 & .831 \\
\hline $\begin{array}{l}\text { Not belonging to a group hinders } \\
\text { access to credit by MSMEs }\end{array}$ & 324 & 1 & 5 & 1.78 & .734 \\
\hline GRANDMEAN SCORE & & \multicolumn{4}{|c|}{3.37} \\
\hline
\end{tabular}

\section{Source: Field Data (2020).}

Basing on the findings, lack of collateral hinders access to credit by MSMEs to a large extent $($ Mean $=4.14, \mathrm{SD}=$ 0.767). Also, lack of guarantors hinders access to credit by MSMEs largely (Mean $=4.10, \mathrm{SD}=0.711)$. Further, additional charges on loans hinder access to credit by MSMEs to a large extent $($ Mean $=3.87, \mathrm{SD}=0.713)$. In addition, short repayment period largely hinders access to credit by MSMEs (Mean $=3.70, \mathrm{SD}=0.793$ ). Lack of sufficient information hinders access to credit by MSMEs moderately $($ Mean $=3.41, \mathrm{SD}=0.892)$ and lack of savings accounts by MSMEs also moderately hinders access to credit by MSMEs (Mean = 3.13, SD = 0.870). Lack of books of accounts by MSMEs hinders access to credit by MSMEs moderately $($ Mean $=2.80, \mathrm{SD}=0.831)$, however, not belonging to a group hinders access to credit by MSMEs to a small extent $($ Mean $=1.78, \mathrm{SD}=0.734)$. Overall, the items on access to credit summed up to a mean of 3.37 implying that the aforementioned factors on average would hinder access to 
credit moderately. This also implies that financial innovations could be important in increasing chances to access credit.

\section{iii. Correlation Analysis}

Correlation provided a basis for further analysis using regression models. Correlation analysis was used to establish and explore the associative relationship between the study variables. Correlation coefficient is the measure to quantify such degree of relationship of the variables. The first test of correlation was formulated by Karl Pearson in 1896.

Table 11 Correlations Matrix
Pearson's Product Moment Correlation Coefficient ( $r$ ) is a scale to measure the strength of linear association between variables.

The coefficient of correlation $\mathrm{R}$ will range between -1 and +1 , i.e., $-1 \leq \mathrm{R} \leq+1$. Correlation coefficient explores the type (positive, negative or none) and, degree of association (magnitude of closeness) between two variables. The current study sought to establish the relationship between monetary intervention measures that may be adopted by monetary authorities and access to credit. Correlation analysis provided useful information on the degree of association between the primary independent dependent variables. The correlations among the variables are shown in Table 11.

\begin{tabular}{llcc}
\hline & & Cash reserve ratio & Access to credit \\
\hline Cash reserve ratio & Pearson Correlation & 1 \\
& Sig. (2-tailed) & \\
Access to credit & $\mathrm{N}$ & 324 & $.649^{* *}$ \\
& Pearson Correlation & .000 & 1 \\
& Sig. (2-tailed) & 324 & 324
\end{tabular}

\section{Source Data: field Data (2020).}

The findings in Table 11 show that the relationship between cash reserve ratio and access to credit was strong, positive and statistically significant ( $r=.649 * *, p<.01)$, (Gathi, et. al.,2019) The results in Table 11 implies that cash reserve ratios plays a positive role in access to credit by MSMEs in Kisumu county. The data in Table 11 shows that the variables considered in the study were correlated hence it was possible to carry out regression analysis.

iv. Regression Analysis

This study was based on the premise that there is a relationship between monetary interventions and access to credit but this relationship is mediated by financial innovations. To test the hypotheses, linear regressions were carried out. First access to credit was regressed against each of the four types of monetary interventions. Next, financial innovations were regressed against the four monetary interventions as a necessary step in testing for the mediating role of financial innovations in the relationship between monetary innovations and access to credit. The results of the tests, performed at the $95 \%$ confidence level, are presented in section 1.4.5.1

\section{v. Cash Reserve Ratio and Access to Credit}

The second objective of the study was the influence of cash reserve ratio on access to credit, the relevant hypothesis tested was that:

$\mathrm{HO}_{2}$ : Cash reserve ratio has no statistically significant effect on access to credit by micro, small and medium enterprises To establish the relationship between cash reserve ratio and access to credit, a regression analysis was conducted. The results obtained are presented in Table $12 \mathrm{a}, \mathrm{b}$ and $\mathrm{c}$ respectively.

\section{Table 12a Model Summary}

\begin{tabular}{ccccc} 
Model & $\mathrm{R}$ & R Square & Adjusted R Square & Std. Error of the Estimate \\
\hline $.649^{\mathrm{a}}$ & .421 & .419 & .58713
\end{tabular}

a. Predictors: (Constant), Cash reserve ratio

Source: Primary Data (2020)

Results in Table 12a showed that cash reserve ratio predicts $42.1 \%$ variations in access to credit $\left(\mathrm{R}^{2}=.421\right)$. Table 12b ANOVA ${ }^{\mathrm{a}}$

\begin{tabular}{llrrrrr}
\hline Model & & Sum of Squares & Df & Mean Square & F & \multicolumn{1}{c}{ Sig. } \\
\hline 1 & Regression & 69.393 & 1 & 69.393 & 201.305 & $.000^{\mathrm{b}}$ \\
& Residual & 95.487 & 323 & .345 & & \\
& Total & 164.880 & 324 & & & \\
\hline
\end{tabular}

a. Dependent Variable: access to credit

b. Predictors: (Constant), cash reserve ratio.

Source: Primary Data (2020)

The results in ANOVA table reveal that the relationship between Cash reserve ratio and access to credit by MSMEs is statistically significant $(\mathrm{F}=201.305, \mathrm{p}<0.05)$. Thus, the model was fit to predict access to credit using cash reserve ratio. 
Table 12c Coefficients ${ }^{\mathrm{a}}$

\begin{tabular}{|c|c|c|c|c|c|c|}
\hline \multirow[b]{2}{*}{ Model } & & \multicolumn{2}{|c|}{$\begin{array}{c}\text { Unstandardized } \\
\text { Coefficients }\end{array}$} & \multirow{2}{*}{$\begin{array}{c}\text { Standardized } \\
\text { Coefficients } \\
\text { Beta }\end{array}$} & \multirow[b]{2}{*}{$\mathrm{T}$} & \multirow[b]{2}{*}{ Sig. } \\
\hline & & $\mathrm{B}$ & Std. Error & & & \\
\hline 1 & (Constant) & 1.631 & .169 & & 9.638 & .000 \\
\hline & $\begin{array}{l}\text { cash reserve } \\
\text { ratio }\end{array}$ & .703 & .050 & .649 & 14.188 & .000 \\
\hline
\end{tabular}

a. Dependent Variable: access to credit

\section{Source: Primary Data (2020)}

The results indicate a linear dependence of access to credit on cash reserve ratio set by the central bank. They also indicate that a unit change in cash reserve ratio would lead to a change in access to credit by 0.649 . The findings are similar to those obtained in previous studies on the effectiveness of cash reserve ratio as a tool of monetary policy. For instance, in Nigeria Onoh and Nwachukwu (2017) found that there was a positive relationship between cash reserve ratio and loan advances of commercial banks. Another Nigerian study on financial intermediation and monetary policy effectiveness revealed that cash reserve ratio had a positive and significant impact on demand deposit (Okoro, et al., 2018). Jamel et al., (2017) established that reserve requirements had a positive effect on money supply in Jordan.

In Kenya, a study by Kimani (2013) established that cash reserve ratio had an influence on the lending behavior of

\section{Table 13 Summary of Research objective, hypothesis and conclusion}

Objective Hypothesis

banks in Kenya (Kamau, 2015). In relation to supply of money, Njiru (2016) found that cash reserve ratio had a negative effect on credit supply in Kenya. It may be concluded that the findings in Table 12 lend support to earlier related studies on the influence of cash reserve ratio on access to credit.

From the results in Table 12 it is evident that there is no support for the hypothesis that there is no statistically significant relationship between cash reserve ratio and access to credit. Thus the hypothesis that there is a statistically significant relationship between cash reserve ratio and access to credit by MSMEs is supported by the data in Table $12 \mathrm{~b}$. The regression equation of the results is: $\mathrm{Y}=\beta_{0}+\beta_{2} \mathrm{X}_{2}+\varepsilon$; $\mathrm{Y}=1.631+0.703 \mathrm{X}_{2}+\mathrm{e}$. Table 13 below summarizes the research objective, hypothesis and conclusion.

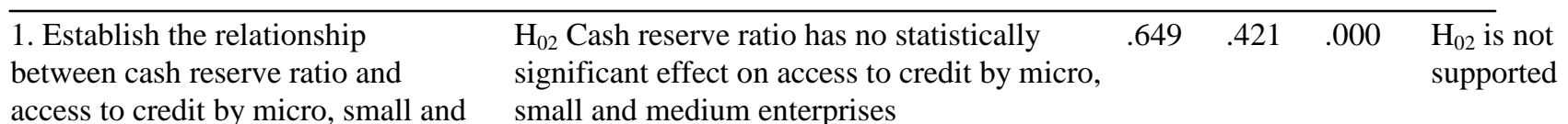
access to credit by micro, small and small and medium enterprises medium enterprises.

\section{Source: Primary data (2020)}

Table 13 provides a summary of the direct effect of monetary interventions on access to credit by MSMEs. From the results of hypothesis test in Table 13 it can be concluded that there is a statistically significant relationship between monetary interventions and access to credit. The conceptual framework hypothesized that there is a statistically significant relationship between cash reserve ratio and access to credit.

\section{SUMMARY OF FINDINGS}

The overall objective was to assess the relationship between monetary interventions and access to credit by micro, small and medium enterprises in Kisumu County, Kenya.

Descriptive and inferential statistics were used to present the results of data analysis. Key findings are summarized in 1.5.1 -1.5 .3 .

\section{A. Descriptive Results}

\section{THE RELATIONSHIP BETWEEN CASH RESERVE RATIO AND ACCESS TO CREDIT}

The objective of the study was to establish the relationship between cash reserve ratio and access to credit by micro, small and medium enterprises. Descriptive analysis established that an increase in the cash reserve ratio moderately decreases access to credit by MSMEs.

\section{ACCESS TO CREDIT BY MSMES IN KISUMU COUNTY}

The results of the descriptive analysis show that the impediments to access to credit by MSMEs: lack of collateral, lack of guarantors, additional charges, short repayment periods, lack of sufficient information, lack of savings accounts, lack of books of accounts and not belonging to a group, had hindered MSMEs from accessing credit to a moderate extent.

\section{B. Correlation Analysis}

The study sought to use regression analysis to test the relationship between monetary interventions and access to credit by MSMEs. As an initial step, the existence or relationships among the variables was established using correlation analysis. Correlation analysis was used to measure the strength of linear association among the study variables. The results showed that the relationship between cash reserve ratio and access to credit was strong, positive and statistically significant.

\section{Regression Analysis}

Access to credit was regressed on cash reserve ratio to test the null hypothesis that cash reserve ratio has no statistically significant influence on access to credit. The null hypothesis 
was rejected and the alternative accepted which states that cash reserve ratio has a statistically significant influence on credit access.

\section{CONCLUSION AND RECOMMENDATIONS FOR POLICY IMPLICATION}

The study set out to investigate the relationship between cash reserve ratio and access to credit among MSMEs. The major conclusion that arises from the findings is that cash reserve ratios have a statistically significant effect on access to credit by micro, small and medium enterprises. It may be concluded that micro, small and medium enterprises' access to credit depends on the direct effects of cash reserve ratio.

The current study makes a substantial contribution to the theory and practice of small business finance in two ways. First, it extends finance scholarship to micro, small and medium enterprise context by explaining the relationship between cash reserve ratio and access to credit by MSMEs.

A major contribution to knowledge is in explaining the mechanism by which monetary interventions influence access to credit in small firms. Such firms are often unable to access bank credit owing to lack of security and the high cost of credit. In particular, it clarifies the mechanism through which monetary interventions influence access to credit. From the findings, we can conclude that MSMEs can have access to credit if the central bank uses cash reserve requirements. These findings have far reaching and practical applications and implications for management of MSMEs, Central banks, bank and non-bank financial institutions. Further, they add substantially to the theory of small business finance, in an emerging economy context.

In line with the study objective and corresponding findings of this study, a recommendation can be made for the theory, policy and practice of small business finance. The empirical nature of the study provides empirical evidence on the direct influence of cash reserve ratio on financial inclusion of micro, small and medium enterprises.

The findings have several practical applications in the management of finances in the small business sector. First, cash reserve ratio is a prudent option for central banks in their bid to influence demand and supply of money in the small business sector. Central bank monetary policy managers can enhance financial inclusion of micro, small and medium businesses by focusing on controlling cash available for making credit. The current study can make several recommendations to the central monetary authority from the finding that cash reserve ratio increase lending to micro, small and medium enterprises. Such interventions should focus on controlling interest rates, through placing of a minimum rate on deposits and a maximum rate on loans targeting the sector and persuading lenders to make preferential loans targeting the sector.

The aim of these monetary interventions ought to be an improvement in their direct effect on financial inclusion of micro, small and medium enterprises. Thus from the study findings, policy makers ought to aim at enhancing access by deploying sector specific interventions in favor of blanket interventions. In addition to policy implications, findings suggest that access to finance in the micro, small and medium sector can be improved through sector specific monetary interventions. In particular, any policies targeting the sector ought to leverage on the significance of the ability of banks to create credit from the cash they hold. Further, by developing monetary policies that are specific to the micro, small, and medium enterprise sector, their contribution to solving of unemployment problems can be enhanced.

\section{ACKNOWLEDGMENT}

I acknowledge The Kisii University coordinating team, under the supervision of Dr. Chesoli Wafula and Prof. Ngacho Christopher, for permitting me to carry out this study. More so, I acknowledge the Almighty God for enabling me to brave the many years of research work because of the joy that was set before me: the joy of accomplishing what God in His infinite mercies helped me to start. To God be the glory.

\section{REFERENCES}

[1] Abdi, F., \& Lodhi, S. (2015). Impact Of Changes In Reserve Requirement On Banks' Profitability: Acase Study Of Commercial Banks In Pakistan. European Journal of Business and Management, 7(31), 95-102.

[2] AFI. (2016). The Role Of Financial Regulation In Promoting Access To Finance By Msmes: Lesson From The AFI Network, Kuala Lumpur https://www.afi-global.org/sites/default/files/publications/2016-08/AF I_SME_WG_guideline note_AW_digital.pdf

[3] Alemu, B. (2017). The Challenges of Financing Growth Oriented Mses: The Case Study Of Hawassa City Mses, Ethiopia. Research Journal of Finance and Accounting, 8(9), 2737.

[4] Aress, A. B. (2012). The Effects of Monetary Policies On Interest Rates in Kenya. https://www.ijbcnet.com/3-8/IJBC-14-3802.pdf

[5] Arora, R. U. (2010). Measuring Financial Access. Griffith Business School Discussion Papers Economics.

[6] Avevor, E. E. (2016). Challenges Faced By Smes When Accessing Funds From Financial Institutions In Ghana. https://core.ac.uk/download/pdf/38137529.pdf

[7] Babbie, R. (2003). The Practice of Social Research Earl

[8] Barata, J. R., Gonzalez, R. B., \& Berrardus, F. N. (2017). Credit Supply Responses To Reserve Ratio: Loan-Level Evidence From Macro-Prudential Policy. BIS Working Papers.

[9] Barus, J. J., Muturi, W., Kibati, P., \& Koima, J. (2017). Effect of Liquidity on Financial Performance of Savings and Credit Societies in Kenya. International Journal of Finance, 2(7), 34-47.

[10] Bassey, F. A., Tobi, E. G., Bassey, I. F., \& Ekwere, R. E. (2016) Liquidity Management and the Performance of Banks in Nigeria. International Journal of Academic Research in Accounting, Finance and Management Sciences, 6(1), 41-48.

[11] Bawa, A. B., Akinniyi, K. O., \& Njarendy, P. I. (2017). The Effects of Cash Reserve Ratio and Money Supply On the Profitability of Deposit Money Banks in Nigeria. International Journal of Financial Management, 17(4), 25-37.

[12] Bernoth, K., Gebauer, S., \& Schafer, D. (2017). Monetary Policy Implications of Financial Innovation. https://www.europarl.europa.eu/RegData/etudes/IDAN/2017/602042/I POL_IDA(2017)602042_EN.pdf

[13] Bismark, O., Kofi, A. F., Kofi, O. A., \& Eric, H. (2018). Impact of Financial Management Practices on the Growth of Small and Medium Scale Enterprises in Ghana: The Case of Birim Central Municipality. International Journal of Innovation and Research in Educational Sciences, 5(2), 177-184.

[14] Boushnak, E., Rageb, M. A., Ragab, A. A., \& Sakr, A. M. (2018). Factors Influencing Credit Decision for Lending SMEs : A Case Study on National Bank of Egypt. Open Access Library Journa, 5, 1-17.

[15] Cesar C. (2013). The Evolving Role of Reserve Requirements In Monetary Policy. The Business and Economics Research Journal, 6(1), 11-25.

[16] Chih, S. H., Liang, L. W., \& Huang, B. Y. (2018). The Study On The Relationship Between Bank M\&A, Sme Lending Credit Guarantee and Bank Efficiency. Romanian Journal of Economic Forecasting, 21(2), 95-117.

[17] Dallimore, A. (2013). Banking On the Poor: Savings, Poverty and Access to Financial Services in Rural South Africa. The London School of Economics and Political Science.

[18] Deressa, C. E. (2014). MSMEs access for finance in Zambia. Research Journal of Finance and Accounting, 10(2), 2222-2847. 


\section{Relationship between Cash Reserve Ratio and Access to Credit by Micro, Small and Medium Enterprises in Kisumu County, Kenya}

[19] Dhungana, N. T. (2016). Effects of Monetary Policy On Bank Lending in Nepal. International Journal of Business Management Review, 4(7), 60-81.

[20] Edem, D. B. (2017). Liquidity Management and Performance of Deposit Money Banks in Nigeria (1986 - 2011): An Investigation. International Journal of Economics, Finance and Management Sciences, 5(3), 146-161.

[21] Etemesi, M. E. (2017). Credit Access from Commercial Banks And Growth Of Smes In Nairobi CBD. United States International University-Africa.

[22] Evidence Review. (2014). Access to Finance. What Works Center for Economic Growth.

[23] Forero, F. P., \& Vega, M. (2015). The Dynamic Effects of Interest Rates and Reserve Ratios. https://www.bcrp.gob.pe/docs/Publicaciones/Documentos-de-Trabajo/ 2019/documento-de-trabajo-005-2019.pdf

[24] Gathii, K. J., Wamukuru, D. K., Karanja, D., Muriithi, W., \& Maina, K. (2019). Research Methods, Data Analysis \& Defences (Building Competences in Education and Social Sciences Research) (1st ed.) Education and Social Sciences Research Association of Kenya (ESSRAK).

[25] Geiger, M. (2008). Instruments of Monetary Policy in China and Their Effectiveness https://unctad.org/en/Docs/osgdp20082_en.pdf

[26] Gentry, M. L., Hubbard, T. P., Nekipelov, D., \& Paarsch, H. J. (2018) Structural Econometrics of Auctions: A Review. Foundations and Trends in Econometrics.

[27] Ghulam, Y., \& Mumbine, V. E. (2017). Small And Medium Enterprise Demand And Availability In The Euro Area. Small And Medium Enterprise Demand And Availability In The Euro Area, 8(20), 54-65.

[28] Gichuki, J., Oduor, J., \& Kosimbei, G. (2012). The Choice Of Monetary Policy Instrument For Kenya. International Journal of Economics and Management Sciences, 11(9), 1-23.

[29] Gloker, C., \& Towbin, P. (2012). Reserve Requirements For Price And Stability: When Are They Effective? International Journal of Central Banking, 8(1), 13-25.

[30] Gray, S. (2011). Central Bank Balances And Reserve Requirements. IMF Working Paper.

[31] Hagabirema, K., \& Kungu, G. K. (2020). Business Support Service and Performance of Small Medium Enterprises in Rwanda: Case of BDF Supported SMEs in Gicumbi District. International Journal of Scientific and Research Publications (IJSRP), 10(4), 775-786.

[32] Haritone, Shikumo, D., \& Mirie, M. (2016). Determinants of Lending to Small and Medium Enterprises by Commercial Banks in Kenya IOSR Journal of Economics and Finance, 07(04), 57-63.

[33] Heng, D. (2015). Impact Of The New Financial Services Law In Bolivia On Financial Stability And Inclusion. IMF Working Paper.

[34] Indimuli, S. O., Mukami, J., Lambart, S., \& Mwangi, N. (2015). Jua Kali in Kisumu: History, Opportunities and Challenges https://macleki.org/stories/jua-kali-in-kisumu/

[35] Jamel, A. H., Alqalawi, R. U., Ahmed, A. A., \& Rasha, M. S. I. (2017) The Influence Of Tools On Price and Output: The Case of Jordan (1993-2013). Banks and Bank Systems. Banks and Bank Systems, 12(1), 8-13.

[36] Jude, F. A., \& Adamou, N. (2018). Bank Loan Financing Decisions of Small and Medium-Sized Enterprises: The Significance of Owner/Managers' Behaviours. International Journal of Economics and Finance, 10(5), 231-241.

[37] Kamau, H. M. (2015). The Effect Of Monetary Policy On Commercial Banks' Lending Rates In Kenya. University of Nairobi.

[38]

[39] Kasera, C. O. (2013). Determinants Of Financial Constraints On Small, Medium Enterprises In Kisumu County, Kenya. University of Nairobi.

[40] Kesale, A. M. (2017). Barriers Facing Startup Small and Medium Enterprises (SMEs) In Accessing External Capital in Tanzania. International Journal of Academic Research in Business and Social Sciences, 7(3), 55-72.

[41] Kigabo, T. R., \& Gichondo, A. (2018). Excess Liquidity and Rwanda's Monetary Policy. East African Research Papers in Economics and Finance. EARP-EF.

[42] Kimani, J. (2013). Assessment Of Effects Of Monetary Policies On Lending Behavior of Commercial Banks In Kenya. Kenyatta University.

[43] Kimathi, P. G., Namusonge, P. G. S., \& Njeru, A. (2016). Credit Accessibility As A Factor For Sustainability Of Women Owned Small And Medium Enterprises In Kenya ( A Pointer To Overcoming Poverty Challenges In Kenya And The Region ). IOSR Journal of Business and Management (IOSR-JBM, 18(2), 7-14.
[44] Kimberlin, C. L., \& Winterstein, A. G. (2008). Validity And Reliability Of Measurement Instruments Used In Research (Research Fundamentals). American Journal of Health System Pharm, 65(1) 275-284.

[45] Kinyumu, J. M. (2013). Operational Challenges In The Growth Of Small And Medium Enterprises In Kisumu County, Kenya. University of Nairobi.

[46] Koila, L. J. (2016). The Effect of Monetary Policy On Inflation Rate In Kenya. University of Nairobi.

[47] Komollo, F. O. (2010). Regularizing The Informal "Jua Kali" Activities In Nairobi For Sustainable Development. 46th ISOCARP Congress 2010.

[48] Kothari, C. R. (2004). Research Methodology. New Age International (P) Ltd, New Delhi.

[49] MacCathy, J. (2016). Effects Of Cash Reserve Ratio On The Financial Performance Of Commercial Banks And Their Engagement In Corporate Social Responsibility In Ghana. Research Journal Of Finance, 4(3), 74-85.

[50] Mahembe, E. (2011). Review On Smes Access To Credit And Support In South Africa. National Credit Regulator (NCR).

[51] Maina, M. W. (2015). Determinants Of Interest Rate Spread Among Commercial Banks Of Kenya. Jomo Kenyatta University of Agriculture and Technology.

[52] Micheal, V. P. (2000). Research Methodology In Management. Himalaya Publishing House, Mumbai.

[53] Milosevic, V. (2014). Uses and Limitations Of Reserve Ratio Policy In Montenegro. Journal Of Central Banking Theory And Practice, 2(3), 25-35.

[54] Mole, S. A., \& Namusonge, G. S. (2016). Factors Affecting Access to Credit By Small and Medium Enterprises: A Case of Kitale Town. The International Journal of Social Sciences and Humanities Invention, 3(10), 2904-2917.

[55] Mukatia, F. (2016). Influence of Financial Literacy on Performance of Small and Medium Entreprises: a Case of Butere Sub County Kakamega County Kenya. Africa Int Ernation Al Journal of Management Educ Ation and Gov Ernanc e (AIJMEG), 1(2), 33-43.

[56] Mutiria, M. (2017). Factors Affecting Small And Medium Enterprises Access To Finance: A Case Study Of Kiambu County. United States International University-Africa.

[57] Mwende, M. J., Muturi, P. W., \& Njeru, D. A. (2019). Effect of Equity Finance on Financial Performance of Small and Medium Enterprises in Kenya. International Journal of Business and Social Science, 10(5), 113-124.

[58] Ndemi, E. G. (2018). Formal Credit Financing and Financial Performance of Small and Medium Enterprises in Nanyuki Town, Kenya. International Academic Journal of Economics and Finance, 3(2), 179-196.

[59] Ndinda, M. D., Ngige, L. W., \& Muia, D. M. (2018). Contribution of Youth Self Help Group Initiatives to Socio- Economic Wellbeing of Youth in Dandora, Nairobi City County, Kenya. Journal of Economics and Finance (IOSR-JEF), 9(2), 20-27.

[60] Ndugbu, M. O., \& Okere, P. A. (2015). Monetary Policy And The Performance Of Deposit Money Banks: The Nigerian Experience. European Journal Of Business And Management, 7(17), 35-45.

[61] Ngumbau, J. M., \& Kirimi, D. (2017). Relationship Between Table Banking And The Growth Of Women Owned Micro And Smal Enterprises In Uhuru Market, Nairobi County. International Academic Journal of Human Resource and Business Administration, 2(3), 580-598.

[62] Njagi, I. K., \& Kariuki, S. (2017). Equity Financing and Financial Performance of Small and Medium Enterprises in Embu Town, Kenya International Academic Journal of Economics and Finance, 2(3), $74-91$

[63] Njiru, F. A. K. (2016). Effects Of Monetary Policy On Credit Supply In Kenya. University of Nairobi.

[64] Nkwabi, J. M., \& Mboya, L. B. (2019). A Review of Factors Affecting the Growth of Small and Medium Enterprises (SMEs) in Tanzania. European Journal of Business and Management, 11(33), 1-8. https://doi.org/10.7176/ejbm/11-33-01

[65] Nto, P. O. O., Mbanasor, J. A., \& Osuala, A. E. (2012). Influence Of Monetary Policy Variables On Loan Supply To Smes In Nigeria. International Journal of Economics and Finance, 4(7), 158-164.

[66] Nzibonera, E., \& Waggumbulizi, I. (2020). Loans And Growth Of Small-Scale Enterprises In Uganda: A Case Study Of Kampala Centra Business Area. African Journal of Business Management, 14(5), 159-169.

[67] Okoro, A. (2018). Financial Intermediation And Monetary Policy Effectiveness In Nigeria. International Review Of Management And Marketing, 3(4), 56-64. 
[68] Onoh, J. O. \& Nwachukwu, T. (2017). Monetary policy and credit delivery in commercial banks: Evidence from Nigeria. International journal of social sciences and management research, vol3, No.7.

[69] Orinda, R. (2014). Financial Challenges Facing Small And Medium Enterprises In Kisumu City Kenya And Their Performance Implications. University of Nairobi.

[70] Peydro, J., Polo, A., \& Sette, E. (2017). Monetary Policy At Work, Security And Credit Application Registers Evidence. Barcelona Graduate School of Economics.

[71] Pirovara, M. (2014). Essay On Financial Integration And Monetary Policy In Small Open Economies. https://www.research.manchester.ac.uk/portal/files/54558578/FULL_ TEXT.PDF

[72] Rono, L. daisychelangat. (2018). Microcredit and Its Relationship To the Growth of Small and Medium Enterprises in Konoin Subcounty, Kenya. International Journal of Advanced Research, 6(4), 961-968.

[73] Ryan-Collins, J. J. (2016). Credit Creation, Monetary Policy And The Macro Economy: Three Empirical Studies. University of Southampton.

[74] Saunders, M., Lewis, P., \& Thornhill, A. (2003). Research Methods For Business Students. Pearson Educational Limited, England.

[75] Sharma, P. (2018). An Empirical Research On Micro Small And Medium Enterprises In Jodhpur Region With Special References To Skill Efficiency And Technology. International Journal of Research and Analytical Reviews, 5(3), 819-825.

[76] Singh, A. S., \& Masuku, M. B. (2014). Sampling Techniques And The Determination Of The Sample Size In Applied Statistics Research: An Overview. International Journal Of Applied Statistics, Commerce And Management,II(II), 78-83.

[77] Ulwodi, W. (2013). Financial Inclusion And Welfare: Evidence From The Global Findex And Financial Access Survey. University of Nairobi.

[78] United Nations. (2015). Eradicating Extreme Poverty And Hunger. The Millennium Development Goals Report.

[79] Waithaka, T. (2014). Corporate Identity Management Practices, Organizational Characteristics, Corporate Image And Brand Performance. University of Nairobi.

[80] Zheng, L., \& Spiegel., M. M. (2017). Reserve Requirement As A Chinese Macro Policy Tool. Research from Federal Reserve Bank of San Francisco.

[81] Zuzana, F., Nuutilainen, R., \& Weill, L. (2015). Reserve requirements and bank lending channels in China. https://www.cb.cityu.edu.hk/ef/doc/GRU/WPS/GRU\%232016-008 Laurent.pdf

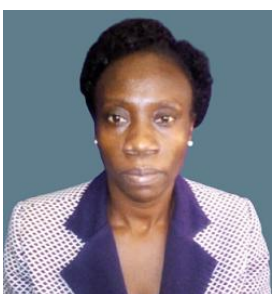

Rosalyne Adhiambo Osir is a holder of a Bachelor of Education (Arts) and a Master in Business Administration (Finance) all from Kenyatta University. This is her second publication. The first is on the relationship between Interest Rate Cap and Access to Credit among Micro, Small and Medium Enterprises in Kisumu County. She has done two major research works during her master and doctorate programmes respectively, all centering on MSMEs. Currently, she is a Principal Vocational Technical Trainer at The Kisumu National Polytechnic in Kisumu, Kenya, in the department of Business. 